\title{
Environmental and occupational respiratory diseases - 1041. The evaluation of the role of obesity on adults with bronchial asthma
}

\author{
Tanja Grzetic-Romcevic ${ }^{1 *}$, Silvana Sonc ${ }^{1}$, Boris Devcic ${ }^{2}$, Tanja Grzetic-Romcevic ${ }^{1}$ \\ From 2nd WAO International Scientific Conference (WISC 2012) \\ Hyderabad, India. 6-9 December 2012
}

\section{Background}

Data on the association between obesity and asthma outcomes are clinically important and not always well understood. AIM: to evaluate the impact of obesity on asthma control and clinical course of the disease.

\section{Methods}

Between January 2011 and December 2011, a total of 293 consecutive asthmatic adult patients (56.7\% female, $43.3 \%$ male) attending to our out-patients clinic (Sezana) were involved in the study. The diagnosis of asthma was assessed according to Global Initiative for Asthma (GINA) guidelines. Asthma control was assessed by Asthma Control Test (ACT). Information about obesity was collected by measuring BMI (Body Mass Index). Obese patients were defined as a patients with the body mass index $>30$.

\section{Results}

The mean age value was $47+-4.1$ years. 76 patients $(26.1 \%)$ had $\mathrm{BMI}<25 \mathrm{~kg} / \mathrm{m} 2,87$ patients (29.9\%) had BMI 25- 29 $\mathrm{kg} / \mathrm{m} 2$ and 130 patients (44\%) had BMI $>30 \mathrm{~kg} / \mathrm{m} 2$. Almost half of our investigated patients with bronchial asthma were obese. Obese patients were more often female (60\% vs $40 \%)$. According to Asthma Control test scores $67.7 \%$ of our patients had controlled and $32.3 \%$ had uncontrolled asthma (15.8\% partly controlled and $16.5 \%$ uncontrolled). The reverse situation were among obese patients. There were more obese patients in the not well controlled group (33.1\% had uncontrolled and $27.9 \%$ had partly controlled asthma) than in the controlled ones (39\%). The number of asthmatic patients requiring hospitalization or emergency room visit due to asthma (in the

${ }^{1}$ Pulmonary, Hospital Sezana, Sezana, Slovenia

Full list of author information is available at the end of the article investigated period) was higher in obese patients $(6.4 \%$ and $18.6 \%$ respectively), than in nonobese asthmatic patients ( $1.8 \%$ and $1.6 \%$ respectively).

\section{Conclusions}

Our results suggest that obesity is associated with more severe and less controlled asthma, with poor clinical courses.

\section{Author details}

${ }^{1}$ Pulmonary, Hospital Sezana, Sezana, Slovenia. ${ }^{2}$ Clinical Department for Pulmonary Diseases and Allergy, University Clinical Center, Ljubljana, Ljubljana, Slovenia.

Published: 23 April 2013

doi:10.1186/1939-4551-6-S1-P40

Cite this article as: Grzetic-Romcevic et al:: Environmental and occupational respiratory diseases - 1041. The evaluation of the role of obesity on adults with bronchial asthma. World Allergy Organization Journal 2013 6(Suppl 1):P40.

Submit your next manuscript to BioMed Central and take full advantage of:

- Convenient online submission

- Thorough peer review

- No space constraints or color figure charges

- Immediate publication on acceptance

- Inclusion in PubMed, CAS, Scopus and Google Scholar

- Research which is freely available for redistribution 